\title{
Ciri Visual Komik Strip Sunda Opat Madhab Setan dalam Majalah Manglé
}

\author{
Kankan Kasmana ${ }^{1}$, Riama Maslan Sihombing ${ }^{2} \& \operatorname{Irfansyah}^{2}$ \\ ${ }^{1}$ Program Studi Desain Komunikasi Visual, Universitas Komputer Indonesia (Unikom), \\ Kampus IV UG-2 Prodi DKV, Jln. Dipatiukur No. 112-114 Bandung 40132, Indonesia \\ ${ }^{2}$ KK Komunikasi Visual dan Multimedia, Fakultas Seni Rupa dan Desain, \\ Institut Teknologi Bandung, Jalan Ganesa No.10, Bandung, Indonesia \\ Email: melihat2@yahoo.com
}

\begin{abstract}
Abstrak. Opat Madhab Setan, sebuah komik strip yang diterbitkan Manglé, majalah berita, sastra dan budaya Sunda hadir Maret hingga Desember 1988 dalam 42 edisi. Komikus berusaha mengangkat budaya Sunda melalui penggambaran ilustrasi yang khas dalam menyusun unsur visual melalui komposisi cukup kental dengan nilai Sunda dan kesundaan. Penelitian ini bertujuan mengetahui serta memahami bagaimana budaya Sunda direpresentasikan melalui gambar dan tulisan. Selain itu untuk mengidentifikasi unsur-unsur dalam komik, yang menjadi ciri visual dan karakter sebuah komik Sunda. Penelitian menggunakan analisis isi kualitatif untuk membuka dan memaparkan dengan teliti bagaimana unsur-unsur pada sebuah cerita diungkapkan. Dari penelitian disimpulkan komik Opat Madhab Setan memiliki ciri visual, gaya gambar semi realis, banyak menangkap gestur, tidak detail, inkonsistensi ukuran panel dan tidak rapih, tipografi tulisan manual menggunakan huruf besar, dominasi normal baloons, dan panel gabungan interdependen, onomatopea yang khas dalam bahasa Sunda. Budaya Sunda direpresentasikan melalui cerita, penokohan orang Sunda berupa karakterisasi stereotype, gambaran fisik postur, gestur, facial, serta latar Islam digambarkan sebagai sistem religi yang dianut, bahasa yang digunakan bahasa Sunda loma/lancaran. Kampung Sunda dihadirkan melalui arsitektur rumah panggung, gambaran alam dengan budaya sawah dan ladangnya, atribut berupa benda pakai, interaksi sosial, kepercayaan serta nilai-nilai kempimpinan yang ada di masyarakat Sunda.
\end{abstract}

Kata Kunci: budaya; karakter visual; komik; komik strip; Sunda.

Abstract. Opat Madhab Setan, a comic strip published by Manglé; Sundanese news, literature, and culture magazine from March to December 1988 in 42 editions. The comic artist tries to depict Sundanese culture through a distinguished illustration in making up the visual elements by taking into account the compositions of societies and its value. The aims of this research are to discovering and comprehending the way Sundanese culture is represented. In addition, it is also meant to identify the visual criteria in the comic. The qualitative-content analysis is used to describe in details how the elements in particular story revealed through drawings and writings. Based on the analysis, it

Received July $2^{\text {nd }}, 2012$, Revised September $28^{\text {th }}, 2013$, Accepted for publication January $16^{\text {th }}, 2014$. Copyright (C) 2014 Published by LPPM ITB, ISSN: 1978-3078, DOI: 10.5614/itbj.vad.2014.6.2.1 
can be concluded that the comic Opat Madhab Setan has the characteristics of semi-realistic drawings, gestural, not detailed, untidy and inconsistent in its panel size, large font for its manual typography, dominated by normal balloons, interdependent joint panel, and peculiar sundanese onomatopoeic sound effects. The Sundanese culture is represented through stereotype characterization, physical illustration, gestures, facial expression, and background. Islam is illustrated as the belief system being adopted. The nature illustrated through the existence of the rice fields, daily use attributes, social interactions, belief, and the value of leadership among the sundanese society.

Keywords: comic; comic strip; culture; Sundanese; visual character.

\section{$1 \quad$ Pendahuluan}

Komik mengemas karya fiksi ataupun materi faktual melalui gambar dan tulisan. Menurut Danesi [1], komik adalah narasi di dunia modern, komik merefleksikan dunia modern dan membantu mempengaruhinya. Sebagai produk budaya komik juga membantu mengembangkan budaya populer di sebuah komunitas masyarakat. Komik merupakan suatu bentuk pembuatan teks, adalah sarana bagi seseorang menciptakan pesan dan makna. Dipengaruhi oleh latar belakang komikus beserta dunia yang melingkupinya, komik merupakan cara bagaimana seseorang merefleksikan sebuah dunia dalam media kertas.

Bandung merupakan salah satu kota yang tidak bisa lepas dari sejarah komik di Indonesia. Di kota ini komik hadir dalam bentuk buku ataupun muncul dalam media massa, yang disebut sebagai 'komik strip'.

Manglé sebuah majalah berita, sastra dan budaya Sunda, terbit di Bandung, menjadi salah satu kendaraan munculnya komik strip Sunda. Tahun 1985-1994 Manglé menerbitkan komik strip berseri karya komikus Sunda. Banyak diantaranya bertemakan horor, mistis, pemujaan yang dilengkapi humor, gambaran penggunaan teknologi serta perilaku adaptasi budaya barat. Opat Madhab Setan salah satunya, komik buatan Budi Riyanto Karung yang diterbitkan bulan Maret hingga Desember 1988. Ilustrasi komik ini mengisi majalah Manglé dalam 42 kali terbitan, edisi nomor 1136-1177, dan menceritakan tentang pemujaan tokoh utamanya Nden Odah pada 4 jenis setan yakni setan Babi (Raja Begu), setan ular (Raja Ipri), setan raksasa (Buta Hejo) dan setan monyet (Monyet Bodas).

Penelitian ini difokuskan pada ciri visual yang muncul dalam unsur intrinsik berupa penokohan, latar/setting, serta unsur ekstrinsik (rupa) komik berupa gaya ilustrasi, tipografi, panel, balon kata serta onomatopea. Selain itu meneliti bagaimana budaya Sunda direpresentasikan melalui teks dalam komik. Tujuannya mengetahui ciri visual dan karakter komik Opat Madhab Setan yang 
ada dalam majalah Manglé, serta mengetahui dan memahami bagaimana representasi budaya Sunda hadir dalam komik ini.

\section{$2 \quad$ Metode Penelitian}

Pendekatan yang digunakan dalam penelitian adalah kualitatif. Analisis yang digunakan adalah analisis isi atau analisis konten, bertujuan menggambarkan karakteristik pesan yang diasumsikan tercermin dalam berbagai modus informasi, format pertukaran irama, dan gaya, gaya misalnya, aural dan visual [2]. Dalam penelitian ini analisis isi pada prinsipnya digunakan untuk membuka dan memaparkan dengan teliti bagaimana unsur-unsur yang terdapat pada sebuah cerita diungkapkan dalam komik terjalin dan menjadi ciri visual dan karakter sebuah komik Sunda. Menurut Ida [3] dalam tahapan analisis isi kualitatif, peneliti berinteraksi dengan material-material (objek penelitian) yang terdokumentasikan, serta melakukan wawancara sehingga pertanyaan tertentu atau pertanyaan khusus dapat diletakkan pada konteks yang tepat untuk di analisis.

Tahapan penelitian dimulai dengan mengumpulkan data objek penelitian berupa bukti fisik serta studi literatur.

Proses analisis isinya sebagai berikut:

1. Menentukan dan menseleksi unit analisis

Unit analisis dibagi ke dalam 3 bagian besar, menurut Eriyanto [4] diantaranya adalah: Unit Sampel (Sampling Unit), dalam penelitian ini unit sampel yang akan diteliti adalah Komik Opat Madhab Setan 42 edisi yang hadir dalam majalah Manglé nomor 1136-1177 mulai Maret hingga Desember 1988. Kedua adalah Unit Pencatatan (Recording Unit), unit yang dipilih adalah unit pencatatan sintaksis, yakni unit analisis yang mempergunakan bagian atau elemen bahasa dari suatu isi. Studi kasus komik menggunakan teks berupa gambar dan tulisan, maka unit bahasannya berupa gambar potongan adegan. Dengan unit analisis sintaksis ini akan dilihat ciri visual yang menjadi karakter komik Opat Madhab Setan dalam majalah Manglé, dengan melihat dan menghitung kemunculan visual dari beberapa unsur intrinsik yang dipilih. Unit analisis lainnya adalah Unit Konteks (Context Unit). Dalam penelitian ini unit konteksnya berupa Sunda dan kesundaan, dikaitkan dengan bagaimana melihat kemunculan budaya Sunda yang hadir melalui beragam artefak, baik yang yang berwujud berupa bermacam produk benda-benda, atau yang tidak berwujud berupa nilai-nilai dan kepercayaan.

2. Membuat protokol (coding form) dan daftar beberapa item atau kategori untuk menuntun pengumpulan data draft protocol (semacam data collection 
sheet), menunjukkan jumlah kemunculan, dan hal-hal yang terkait dengan kemunculan visual dari setiap unit analisis.

3. Interpretasi merupakan prosedur terakhir, setelah hasil analisis dilengkapi temuan data hasil wawancara serta deskripsi-deskripsi yang terkait dengan objek penelitian.

\section{$3 \quad$ Komik Strip Sunda Opat Madhab Setan}

Komik Strip Sunda Opat Madhab Setan muncul di majalah Manglé, terdapat pada bagian sampul belakang majalah, dan terkadang ada di bagian belakang sampul depan. Dengan format warna hitam dan putih, digambar di atas kertas art paper atau kertas koran, komik ini mengisi 1 halaman di setiap terbitan Manglé tersebut di atas. Komik ini bercerita tentang seorang ibu bernama Odah di sebuah keluarga yang hidup dalam kesengsaraan. Demi merubah nasibnya Odah melalukan pemujaan pada 4 setan yang harus dibayar dengan 'wadal' (pengorbanan nyawa) keluarganya sendiri. Kekacauan terjadi saat ke empat setan datang bersamaan, saling membunuh, dan diakhir cerita wujud Odah berubah menjadi mahluk yang memiliki ciri keempat setan (lihat Gambar 1).

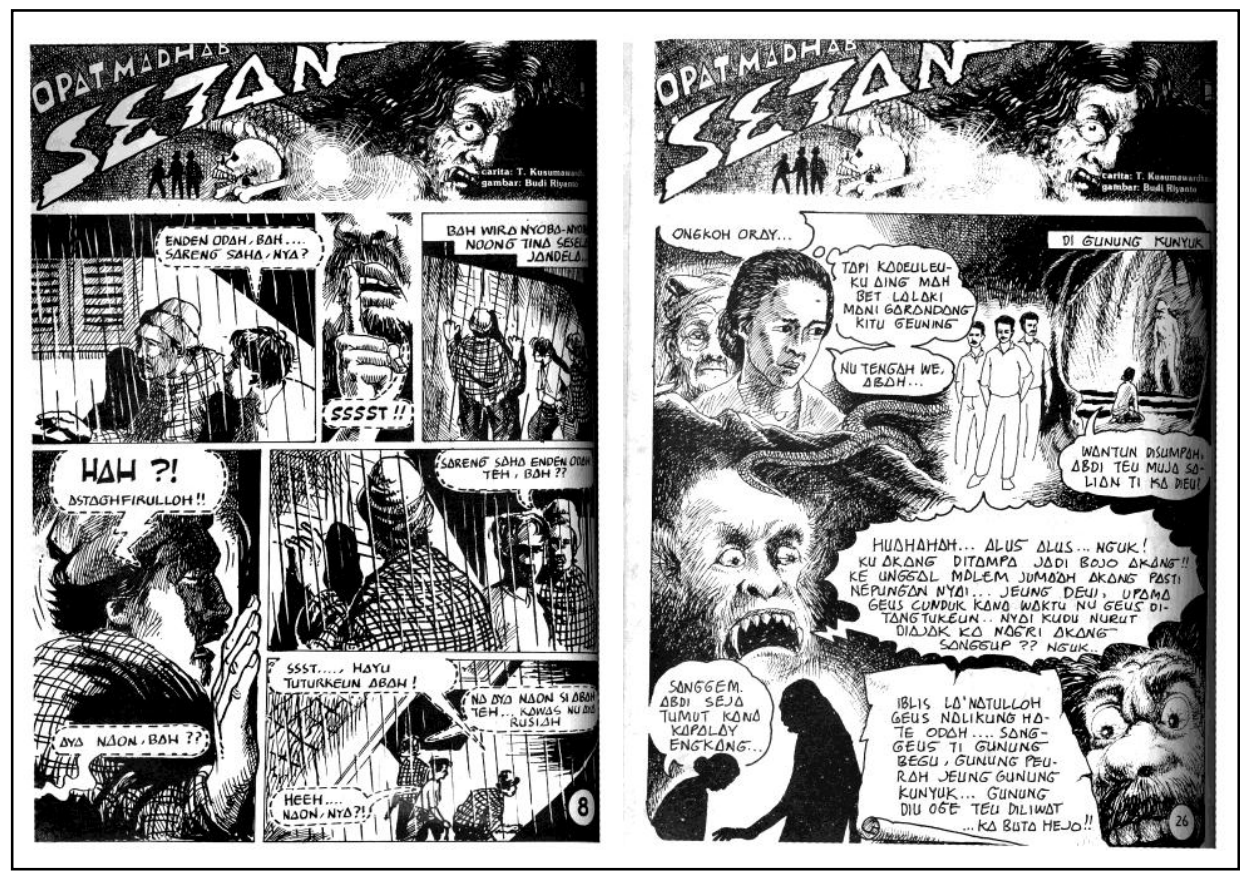

Gambar 1 Ilustrasi komik Opat Madhab Setan [5]. 


\section{$4 \quad$ Analisis Isi}

\subsection{Analisis Unsur Intrinsik}

\subsubsection{Penokohan \& Stereotype}

\section{Tokoh Utama (central character)}

Odah digambarkan sebagai perempuan kaya, dengan penampilan rambut diurai dan mengenakan rok. Berbeda sebelumnya ketika miskin, ia berkebaya dan mengenakan sanggul di kepalanya. Dalam komik ini Odah muncul dalam 4 kondisi, yakni saat kaya (25 kali), saat miskin (9 kali), berubah menjadi babi (4 kali), serta saat berubah wujud menjadi makhluk aneh (1 kali).

\section{Tokoh tambahan (pheriperal character)}

a. Raja Monyet Bodas, Raja Ipri, Buta Hejo, Raja Begu (babi)

Tokoh-tokoh ini digambarkan sebagai antagonis, empat setan, suami Odah. Istilah memuja untuk Raja Monyet Bodas adalah 'ngetek'. Sebagian masyarakat lainnya menyebutnya sebagai 'nyupang' muncul sebanyak 15 kali. Raja Monyet Bodas, wajahnya memiliki kemiripan dengan monyet hutan Maccau, yang dapat ditemukan di hutan-hutan di Jawa Barat. Monyet berwarna putih adalah merupakan pengaruh gambaran tokoh Hanoman dalam mitologi Hindu Mahabarata (Gambar 2).

Raja Ipri, istilah memuja untuk Raja Ipri adalah 'ngipri' dan kediamannya gunung Peurah. Berwujud ular (siluman oray), namun awal saat Odah menemuinya tokoh ini berwujud pria tampan. Muncul dalam wujud ular 15 kali, hadir dalam wujud manusia 1 kali. Tampilannya memiliki kemiripan dengan ular Sanca (phyton) yang juga dapat ditemukan di hutan-hutan atau sawah di Jawa Barat.

Buta Hejo berwujud raksasa berwarna hijau, dengan taring dan hidung besar serta mata yang melotot, berbadan besar dan tambun mengenakan celana cawet. istilah memuja Buta Hejo adalah 'munjung', muncul 22 kali. Buta Hejo menyerupai gambaran buta dalam wayang golek, tubuhnya besar, berbulu, dengan perut tambun, mengenakan gelang dengan bibir dan kumis tebal, mata besar melotot, hidung besar, alis yang tebal, beranting, dan berambut gondrong. Merupakan pengaruh dari mitologi Hindu.

Raja Begu (babi) setan berwujud manusia berkepala babi, istilah pemujaannya adalah 'nyegik', muncul 17 kali. Gambaran babi ngepet (nyegik) adalah seperti babi hutan, dengan bulu hitam dan bertaring. Gambaran babi ngepet adalah seperti bagong atau babi hutan yang ada di Jawa Barat (Gambar 2). 


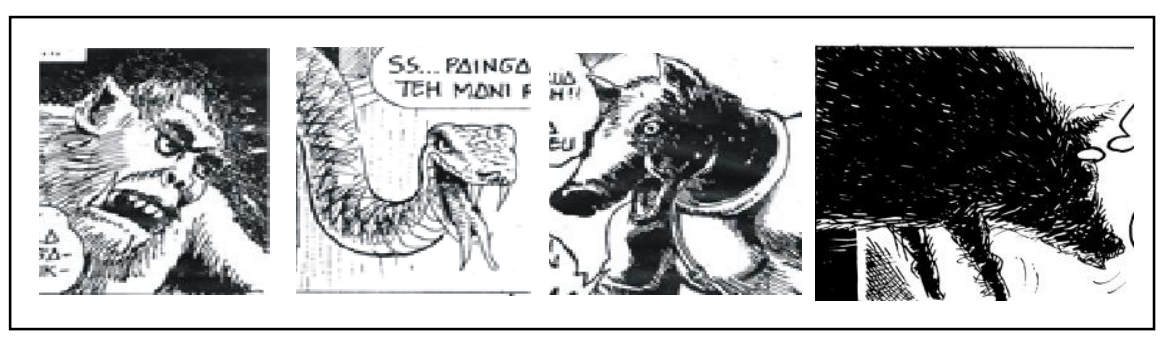

Gambar 2 Stereotype setan di masyarakat Sunda yang ada dalam komik [5].

b. Abah Wira, Otong, Mang Kosim, dan Kardun

Keempatnya merupakan pelaku ronda di malam hari. Abah Wira berumur sekitar 60 tahun, pimpinan ronda beristrikan Ma Onah. Muncul 30 kali dalam komik, tokoh ini muncul cukup sering karena memiliki peran penting dalam cerita.

Otong digambarkan sebagai orang Sunda yang memiliki karakter jenaka dengan perilakunya sendiri. Penakut (borangan), masih muda dan banyak bercanda, muncul 24 kali. Mang Kosim digambarkan sebagai lelaki dewasa yang berkumis, mengenakan sarung, muncul 7 kali.

Kardun adalah pembantu Nden Odah, merupakan gambaran tokoh pembantu yang loyal pada majikan. Selain dituturkan melalui cerita, keloyalan Kardun diperlihatkan melalui sikap tubuhnya yang cenderung membungkuk. Kardun digambarkan bermuka ramah, dengan gigi agak menonjol, mengenakan kaos, celana dan sarung, muncul 52 kali. Ia lebih banyak muncul karena merupakan tokoh yang dekat dengan tokoh utama.

Stereotype tukang ronda digambarkan tokoh-tokoh ini yakni pria yang mengenakan kain sarung sebagai penghangat tubuh, serta kupluk (penutup kepala). Tukang ronda dapat ditemui di belahan daerah di Jawa Barat dan Indonesia pada umumnya (Gambar 3).

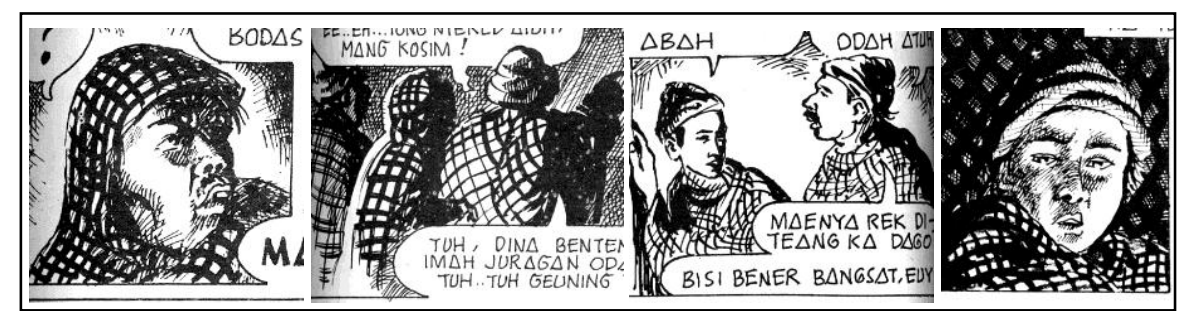

Gambar 3 Gambaran tukang ronda di komik mengenakan kain sarung dan kupluk [5].

c. Mama Ajengan

Tokoh ini dihormati karena pengetahuan agamanya, muncul dalam komik ini di akhir cerita, mengenakan kopiah dan sorban melilit bahunya, muncul 10 kali. 
Stereotype Mama Ajengan atau Ustad, digambarkan mengenakan sorban di leher serta kopiah (topi hitam) sebagai salah satu ciri ustad (Gambar 4).

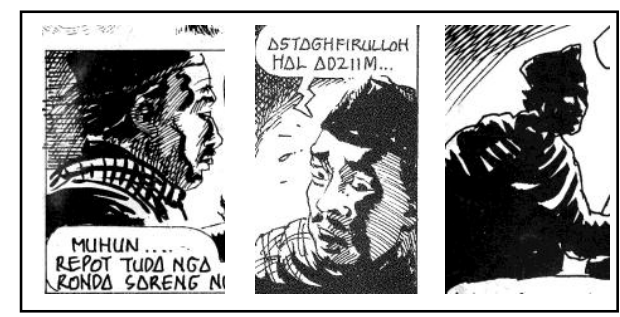

Gambar 4 Mama ajengan; mengenakan kopiah dan sorban di leher [5].

d. Oman, si Aa, Nyi Warsih, Enur, Cecep

Suami dan anak-anak Odah tumbal pesugihan Odah. Oman digambarkan lelaki dengan perawakan kurus, bentuk tulang rahangnya yang menyembul, mengenakan kopiah dan kaos oblong serta sarung, gambaran karakter orang Sunda, muncul 4 kali. Si 'Aa' muncul 2 kali, Nyi Warsih muncul 2 kali, dan Enur muncul 2 kali. Cecep, anak bungsu Odah muncul 1 kali, nama Cecep memiliki kedekatan dengan kata 'kasep' dalam bahasa Sunda yang berarti tampan.

\section{e. Petani}

Lelaki dewasa yang mengenakan topi, celana pangsi dan kaos, serta membawa cangkul, muncul 6 kali, sebagai indeks kampung Nanjung masih terdapat sawah atau ladang.

\section{f. Dukun (kuncen)}

Muncul 3 kali, sebagai stereotype profesi serta kepercayaan yang ada di masyarakat Sunda (Gambar 5).

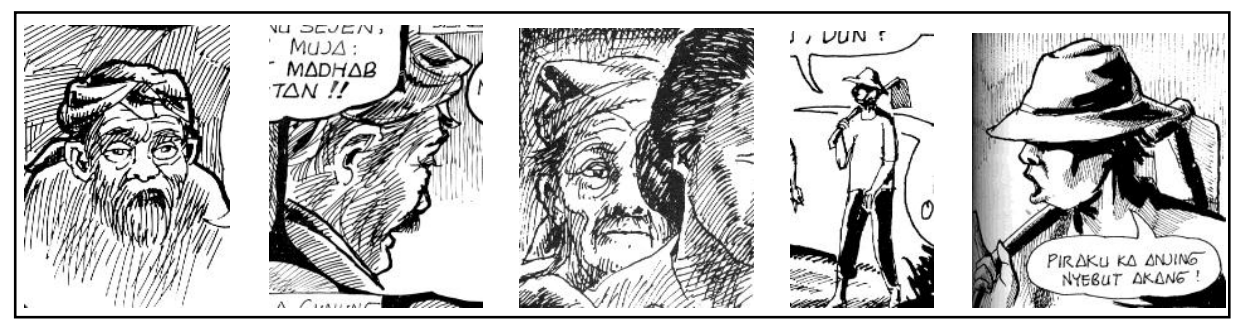

Gambar 5 Tokoh dukun mengenakan iket, dan petani dengan pangsi, dan cangkulnya [5].

Petani digambarkan mengenakan celana panjang yang digulung (pangsi di Sunda) serta mengenakan kaos oblong, dengan membawa cangkul dan topi walaupun biasanya mengenakan dudukuy (topi berbentuk kerucut dari anyaman bambu). 


\section{g. Ma Onah}

Istri Abah Wira, bersanggul, mengenakan kebaya yang ingin tahu urusan orang lain (Gambar 6). Sosok wanita desa yang pengetahuannya pas-pasan, diperlihatkan dengan salahnya pengucapan kreatif menjadi raketip. Muncul 3 kali, menunjukkan stereotype karakter wanita tua Sunda yang sederhana dan lugu dengan segala pengetahuannya.

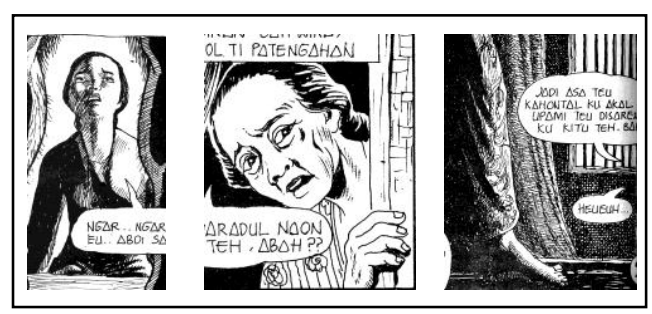

Gambar 6 Stereotype wanita Sunda, Odah dan Ma Onah mengenakan kebaya dan sanggul, serta kain batik [5].

Tokoh wanita muncul hanya sedikit, merupakan gambaran masyarakat Sunda dalam menghargai posisi perempuan. Munculnya banyak tokoh laki-laki di sekeliling tokoh wanita menjadi gambaran perempuan dilindungi, dijaga, mempunyai kedudukan sendiri dalam masyarakat Sunda dan dihormati keberadaannya. Laki-laki berperan sebagai pelindung dan penjaganya. Seperti yang diungkapkan oleh Ayatrohaedi [6], bahwa di masyarakat Sunda, baik yang tradisional ataupun masyarakat masa silam, perempuan mempunyai kedudukan dan peran yang cukup penting. Bahkan, dijelaskan pula terkadang terkesan bahwa kedudukan perempuan itu demikian penting, sedangkan tokoh laki-laki muncul sebagai 'pelengkap' untuk mendukung kehormatan dan kemuliaan perempuan.

Tokoh Odah sebagai tokoh utama muncul lebih sedikit dibanding dengan tokoh pendukung Kardun (pembantunya). Menunjukkan gambaran bentuk egaliterisme di masyarakat Sunda. Posisi Odah sebagai tokoh utama keberadaannya tidak begitu berpengaruh pada jumlah kemunculan. Artinya hirarki tidak muncul dalam komik ini. Seperti yang diungkapkan oleh Hasbullah [7], bahwa corak kebudayaan Sunda adalah kebudayaan rakyat yang egaliter yang mencerminkan kesamaan derajat antar manusia.

\section{Gambaran Fisik dalam Gestur, Postur dan Facial}

a. Gestur

Secara umum gestur yang dimunculkan lebih dominan digambarkan gerakan bagian tubuh saat terkejut, sebanyak 12 kali. Yang menarik dalam gestur pada komik ini, yakni muncul gestur yang dihadirkan melalui gambar disertai istilahistilah yang sangat khas untuk gerakan anggota tubuh spesifik memperlihatkan 
istilah bahasa Sunda yang bila diterjemahkan dalam bahasa Indonesia maka artinya sangat khusus. Contohnya adalah ngajarengkol, yakni sikap tubuh meringkuk seperti buah Jengkol karena kedinginan. Ngorejat yakni bangun dari posisi tidur dengan terkejut. Ngeureuyeuh, yakni melakukan pekerjaan sedikit demi sedikit, terus menerus dan berulang-ulang.

b. Postur

Sedikit gambaran komik yang menangkap pesan postural. Postur yang ditangkap lebih banyak menggambarkan respon terhadap lingkungan (responsiveness), yakni sekitar 4 kali. Sama seperti gestur, yakni terdapat istilah-istilah yang sangat khas untuk gerakan tertentu. Seperti istilah nyangkere, istilah untuk tidur dengan terlentang dan mulut terbuka atau ngagaredig, istilah yang berarti jalan beriringan dengan cepat.

\section{c. Facial}

Dalam komik facial lebih banyak digambarkan dengan pengambilan sudut pandang close up dan extreme close up. Gambaran wajah lebih banyak menangkap gambaran/ekspresi wajah terkejut 5 kali, dan marah 6 kali. Hal ini dikarenakan cerita memiliki konflik yang cukup intens.

\subsubsection{Latar}

\section{Latar Tempat}

Tempat terjadinya cerita dalam komik ini adalah kampung Nanjung di pelataran Sunda, gambarannya desa ini dipenuhi banyak pepohonan, kental dengan suasana desanya dengan adanya rumah tradisional Sunda dan petani. Petani menjadi indeks adanya sawah atau ladang di kampung tersebut.

Sementara itu kejadian digambarkan pada beberapa lokasi yaitu:

- Rumah Odah saat kaya yang sangat mewah dengan dinding tembok semen.

- Rumah Odah saat miskin serta interior bagian tengah rumah Odah yang digunakan Oman dan tiga anaknya tidur.

- Gardu Ronda, tempat ini menjadi latar kedua yang dominan menyerupai saung. Bentuknya seperti rumah panggung kecil namun terbuka, tanpa ada pintu dengan material kayu dan bambu.

Latar tempat lain yang juga digambarkan adalah Gunung Peurah, Peurah (bisa ular), Gunung Kunyuk (monyet dalam bahasa Sunda). Pasar menjadi gambaran interaksi sosial yang terdapat dalam masyarakat Sunda. Kekhasannya ditunjukkan dengan adanya alat transportasi becak dan delman. 


\section{Latar Waktu}

Untuk ceritanya sendiri banyak digambarkan latar waktu malam hari yakni di hari Kamis malam Jumat Kliwon (Gambar 7). Latar waktu malam hari banyak dipadu dengan hujan, latar waktu ini menjadi pendukung suasana mencekam, dan menakutkan.

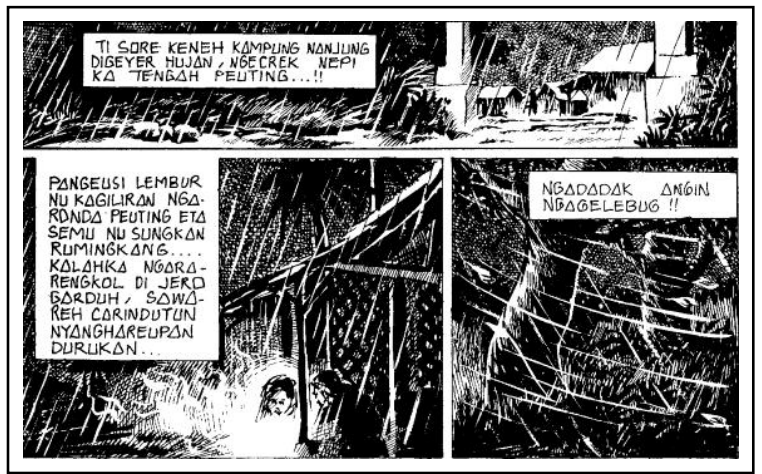

Gambar 7 Latar waktu malam Jumat Kliwon saat Monyet Bodas datang ke kediaman Odah, dan saat penduduk desa melakukan ronda [5].

\section{Latar Sosial}

Nilai-nilai yang masih berlaku digambarkan dengan adanya interaksi sosial yang masih kuat digambarkan dengan adanya gosip di kampung tentang Odah, artinya hubungan kekerabatan antar warga masih cukup kental. Interaksi sosial lainnya hadir melalui sebutan bagi tokoh yang dianggap dituakan, tokoh yang dianggap memiliki kedudukan tinggi dalam strata sosial.

\subsection{Analisis Unsur Ekstrinsik}

\section{Gaya Gambar}

Gaya gambar semi realis dengan arsiran cukup tegas, tidak bersih pada beberapa panelnya. Gambaran komik Opat Madhab Setan tidak terlalu detail menangkap objek, objek hanya ditangkap dalam bentuk posturnya saja serta atribut yang dipakai oleh tokoh-tokoh. Sehingga ada beberapa gambar yang hanya berupa siluet saja (Gambar 8).

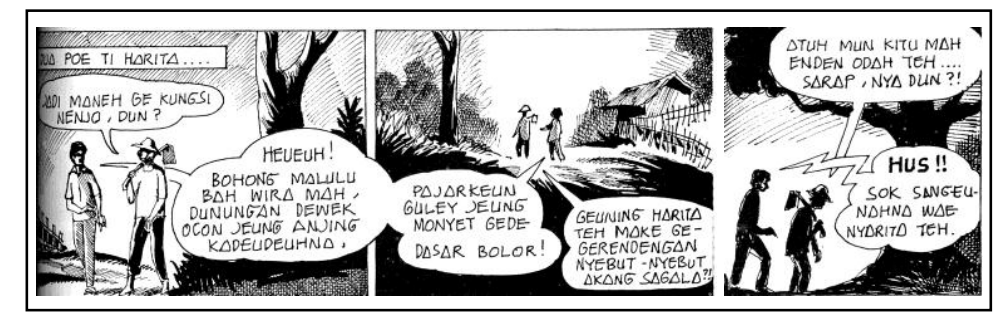

Gambar 8 Objek manusia yang tidak digambarkan dengan detail [5]. 
Dalam komik Opat Madhab Setan, gambaran tokoh banyak diberikan bayangan gelap dan tidak bersih. Membuat latar waktu siang atau malam tidak memiliki perbedaan yang signifikan (Gambar 9).

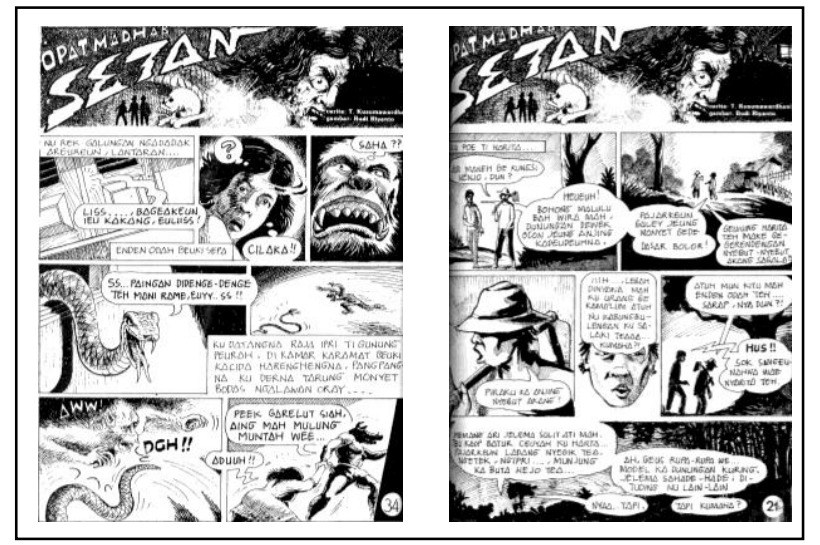

Gambar 9 Nuansa warna yang gelap, serta latar waktu yang sulit dibedakan [5].

\section{Tipografi}

Huruf yang digunakan dalam komik ini adalah custom, huruf yang dibuat sekaligus merupakan tulisan Budi Riyanto Karung sendiri. Huruf tersebut muncul dalam teks judul serta teks dalam panel, balon kata, efek suara, nama pengarang dan komikus. Pada judul "Opat Madhab Setan" huruf Setan dibuat sedemikian rupa, berkesan memberikan nuansa horror (Gambar 10).

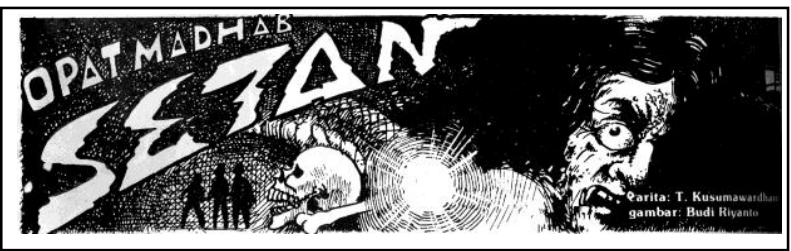

Gambar 10 Tipografi pada judul (text as image) [5].

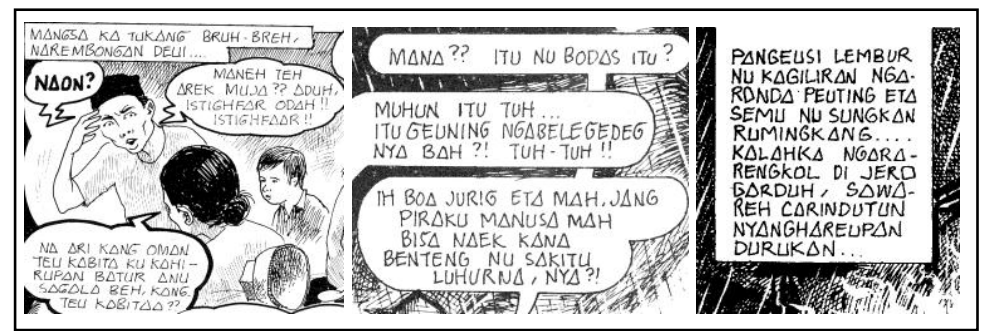

Gambar 11 Tipografi pada teks, merupakan tulisan tangan Budi Riyanto sendiri [5]. 
Tulisan tangan ini menggunakan huruf besar pada setiap teksnya, merupakan tulisan Budi Riyanto Karung. Huruf besar dipilih supaya tulisan lebih jelas, dan kelurusan dan kerapihannya akan tercapai (Gambar 11).

\section{Panel}

Dalam komik ini hanya terdapat dua bentuk panel yakni panel yang menggambarkan keadaan yang sedang terjadi dan panel yang menggambarkan keadaan waktu masa lampau. Panel satu dan lainnya dihubungkan oleh closure. Peralihan atau closure didominasi oleh peralihan adegan yang menunjukkan kesederhanaan dalam menuturkan cerita. Jenis panel yang sering muncul adalah panel yang menunjukkan kejadian saat cerita terjadi sekitar $80 \%$ keseluruhan komik. Bentuknya persegi panjang dengan ukuran yang beragam. Panel dalam komik ini tidak rapih, selain kotor pada jarak yang membatasi panel satu dan lainnya cenderung memiliki ukuran tidak konsisten. Ketidakkonsitenan jarak panel dapat dilihat pada beberapa halaman komik. Begitu juga dengan bagian pinggir dari panel tidak bersih, banyak dijumpai panel-panel dengan kelebihan tinta pada ujung-ujungnya (Gambar 12).

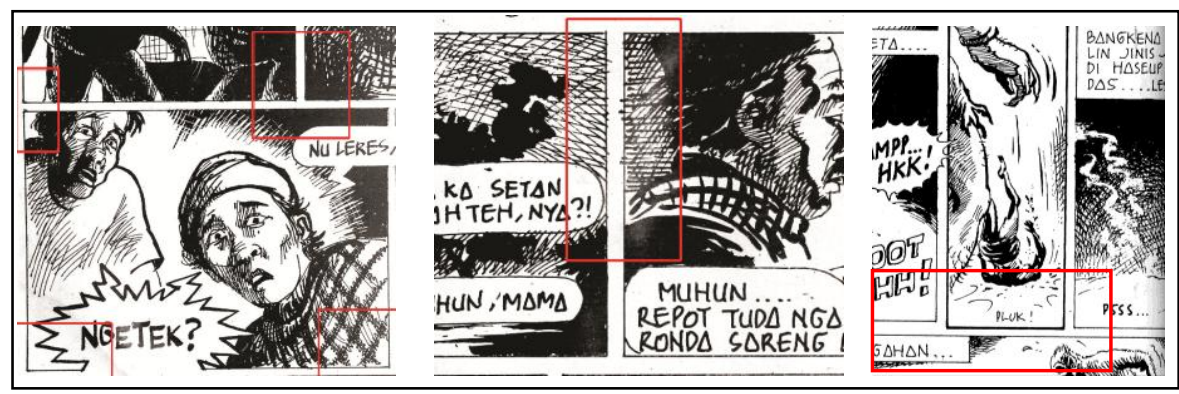

Gambar 12 Bagian sisi panel yang tidak bersih dan ukuran panel yang tidak konsisten [5].

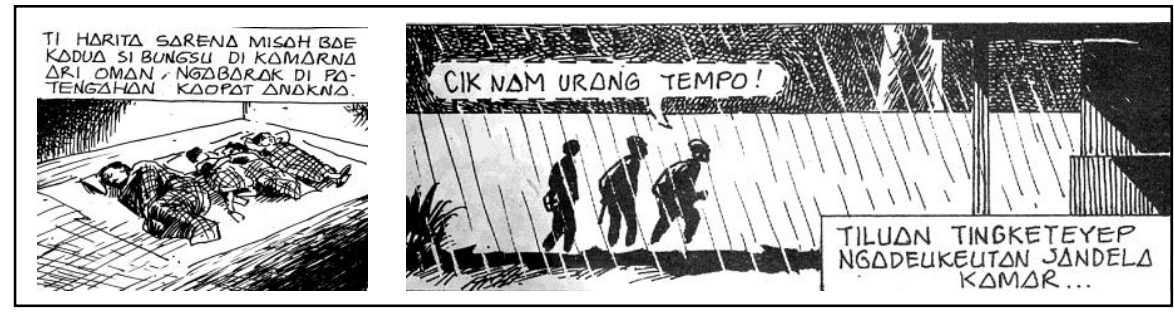

Gambar 13 Istilah ngabarak, tingketeyep yang dijelaskan oleh gambar, begitu pula postur tersebut dijelaskan oleh tulisan (panel gabungan interdependen) [5].

Panel didominasi oleh bentuk panel yang merupakan gabungan interdependen, hampir yakni kata-kata/gambar sama-sama berperan dalam menyampaikan gagasan yang tidak dapat dilakukan oleh salah satu dari keduanya. Dominasi ini 
dapat dilihat pada panel yang memperlihatkan postur atau gestur yang istilahnya khas (Gambar 13). Masing-masing teks (tulisan dan gambar) sama-sama berperan menjelaskan, yang bila dijabarkan dengan tulisan akan sangat panjang.

\section{Balon Kata}

Dalam komik ini terdapat 8 jenis balon kata yang berbeda. Ragam bentuk balon kata yang berkembang menunjukkan adanya pengaruh barat seperti yang diutarakan oleh McCloud [8] bahwa bentuk balon kata akan selalu berkembang. Ciri lainnya yakni dominasi digunakannya normal balloons yakni sekitar 119 kali (balon kata normal untuk menunjukkan bahwa isi dialog adalah percakapan langsung). Melalui dominasi pada balon kata, berupa percakapan langsung, maka dapat dilihat karakter Orang Sunda yang senang berkata-kata, atau berdialog (Gambar 14).

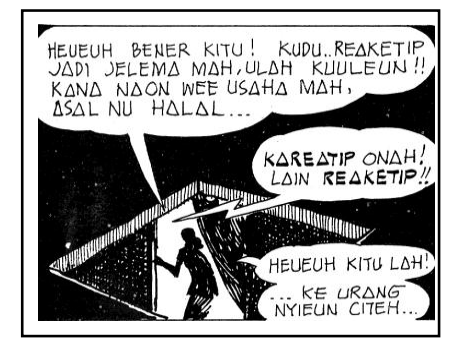

Gambar 14 Bentuk balon kata yang dominan dalam komik ini [5].

\section{Efek Suara}

Efek suara muncul pada komik sebanyak 21 kali. Ungkapan dilafalkan dalam bahasa Sunda berupa tiruan bunyi yang disebut sebagai nomatope/onomatopéa Terdapat lebih dari 15 efek suara yang berbeda, penggambarannya sangat sederhana ada yang berupa tulisan saja, dengan ukuran huruf besar dan kecil namun ada pula yang menggunakan balon kata untuk tipe suara yang keras.

\subsection{Analisis Implementasi Kesundaan dalam Komik}

Gambaran Sunda dan kesundaan pada komik ini hadir melalui kemunculan visual yang menunjukkan unsur kebudayaan yang ada di masyarakat Sunda, berupa:

\section{Bahasa}

Bahasa yang digunakan sebagai pengantar adalah bahasa Sunda loma/lancaran yakni bahasa Sunda yang digunakan dalam kegiatan sehari-hari, tidak kasar atau halus, namun dapat diterima oleh semua kalangan yang berbahasa Sunda. Bahasa ini digunakan sebagai bentuk egaliterisme orang Sunda. Walaupun 
begitu masih terdapat bahasa yang lebih halus (lemes) di sebagian dialognya sebagai bentuk sopan santun dan etika dari yang muda pada orang tua.

Penggunaan nama-tama tokoh di masyarakat Sunda, beberapa nama tokoh adalah nama yang dipengaruhi oleh Islam (bahasa Arab) seperti Kosim (qasim), namun dalam bahasa Sunda tidak dikenal pelafalan huruf Q (qof) sehingga dilafalkan seperti huruf K. Enur dari kata nur (berarti cahaya dalam bahasa Arab), dan Oman kependekkan dari rohman (rahman-dalam bahasa Arab yang berarti pengasih). Nama-nama tersebut merupakan nama panggilan atau nama singkat dari nama sebenarnya. Dalam masyarakat Sunda dikenal dengan istilah lalandihan, yakni nama panggilan, atau nama kesayangan.

Selain itu sebutan yang khas yang ada di masyarakat Sunda diantaranya 'Mang' (panggilan untuk paman), 'Nyi', atau nyai sebutan untuk anak wanita tertua sebagai panutan bagi adik-adiknya, ' $A a$ ' panggilan untuk kakak laki-laki. 'Nden' (raden), panggilan untuk laki-laki atau wanita yang dianggap terhormat di masyarakat Sunda, memiliki kelebihan dalam hal ekonomi, kedudukan, pangkat ataupun keturunan ningrat. Hal ini merupakan pengaruh budaya Jawa yang mengenal hierarki. 'Abah' untuk laki-laki dan ' $M a$ ' (Emak) untuk wanita panggilan untuk orang tua yang dianggap yang dituakan (kokolot dalam basa Sunda).

Hal lain tentang bahasa adalah adanya istilah untuk gestur dan postur tubuh yang khas dan sangat spisifik dalam istilah bahasa Sunda. Diantaranya istilah ngajarengkol, ngorejat, ngajehjer, ngulisik, ngeureuyeuh, tibuburanjat, kuniang cengkat, ngagoler dan 18 istilah gestur, serta 13 istilah postur lainnya. Hal ini menunjukkan kekayaan kosakata dalam bahasa Sunda (Gambar 15).

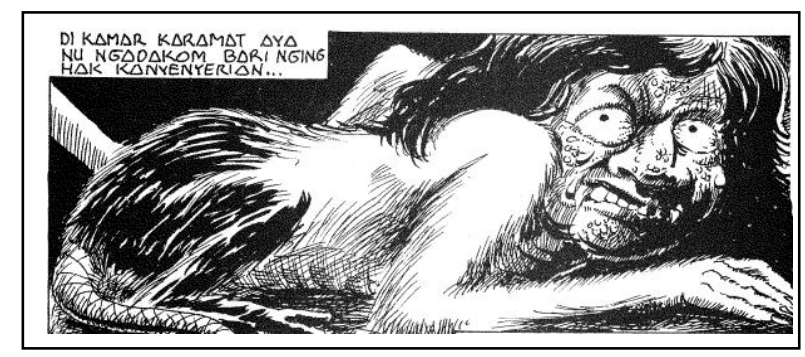

Gambar 15 Ngadakom, posisi tubuh menelungkup seperti baskom terbalik [5].

\section{Organisasi Sosial}

Interaksi dan organisasi sosial hadir melalui sebutan-sebutan bagi tokoh yang dianggap dituakan, tokoh yang dianggap memiliki kedudukan tinggi dalam strata sosial, (bisa berupa kekayaan), serta sebutan untuk mereka yang dianggap sudah tua. Sebutan 'mama' bagi Ustad dalam komik ini (mama Ajengan) 
merupakan arketip kepemimpinan di Sunda, bagaimana orang yang menguasai ilmu agama dianggap sebagai pemimpin yang menentukan sebuah keputusan atau memecahkan masalah. Makna ajengan berarti yang diajengkeun (dikedepankan), pilihan bagi pribadi yang memiliki pengetahuan agama dan lebih dari anggota masyarakat lainnya.

\section{Sistem Peralatan Hidup dan Teknologi}

Arsitektur rumah panggung dengan material bilik bambunya merupakan gambaran teknologi, bagaimana masyarakat Sunda menemukan dan menggunakan material yang berasal dari alam. Rumah tersebut memiliki gambaran seperti rumah di perkampungan Baduy (Gambar 16-17).

Hadir melalui gambaran rumah panggung para pelaku serta gardu ronda yang khas dan menjadi ciri bangunan Sunda. Untuk atribut lainnya, hadir dalam alat bantu atau peralatan yang digunakan dalam pekerjaan sehari-hari (Gambar 18). Seperti boboko (periuk nasi dari anyaman bambu), pacul (cangkul), samak (tikar anyaman daun pandan). Sama seperti pada arsitektur banyak material alat benda pakai yang diambil dari alam. Hal ini menunjukkan pemanfaatan bahan dari alam sebagai bentuk penghargaan terhadap alam itu sendiri, senada seperti yang dikemukakan oleh Rosidi [9] yang menguraikan bahwa Orang Sunda mempunyai anggapan bahwa lingkungan alam memberikan manfaat yang maksimal kepada manusia apabila dijaga kelestariannya, dirawat serta dipelihara dengan baik dan digunakan hanya secukupnya saja. Pandangan tersebut mempengaruhi cara hidup dan cara memperlakukan lingkungan sekitar.

Keranda mayat, delman serta beca menggambarkan bagaimana sistem peralatan hidup dan teknologi masyarakat Sunda dalam transportasi (Gambar 19).

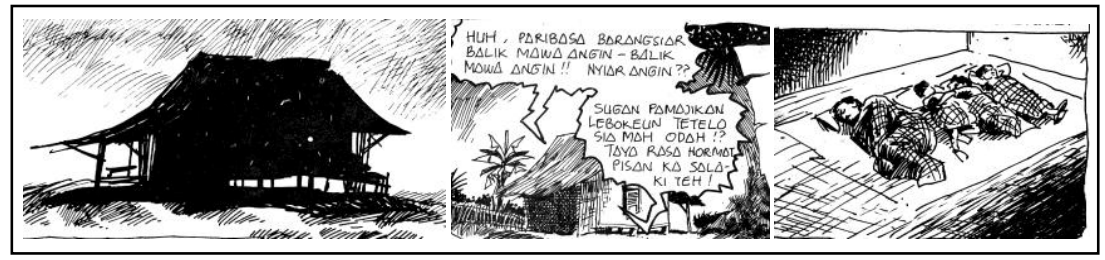

Gambar 16 Rumah Odah saat miskin, serta area tengah rumah [5].

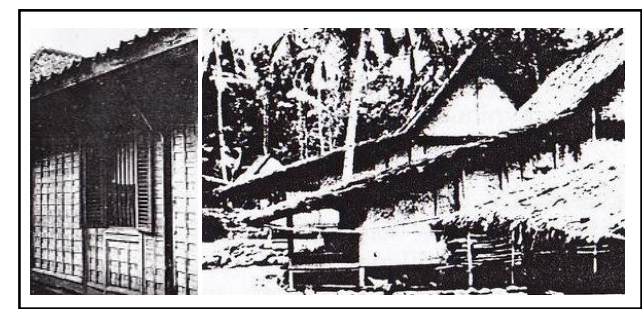

Gambar 17 Arsitektur rumah Sunda tipe daerah Baduy [10]. 


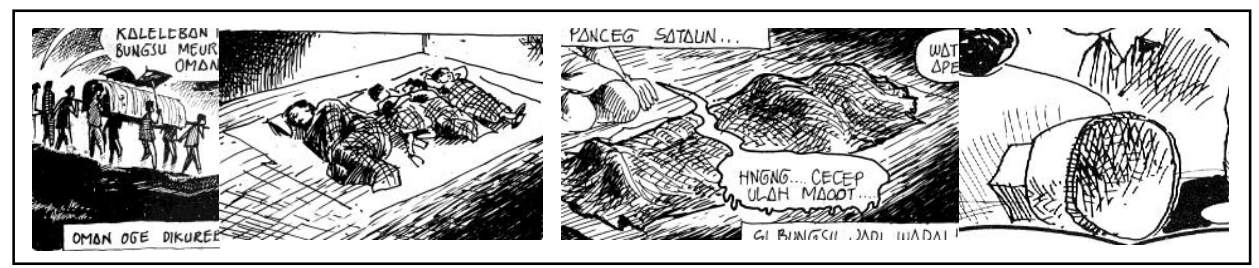

Gambar 18 Atribut yang hadir sebagai sistem peralatan hidup khas Sunda. [5].

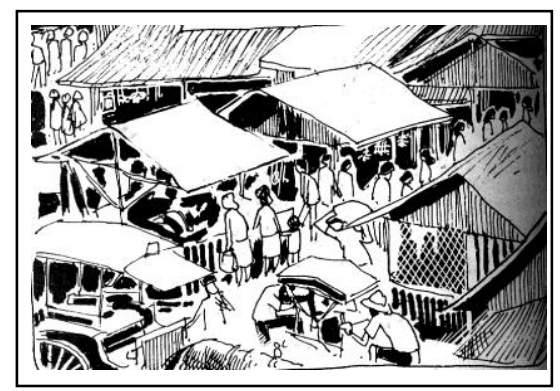

Gambar 19 Delman, Beca alat transportasi yang hadir dalam komik [5].

\section{Sistem Mata Pencaharian}

Sistem mata pencaharian masyarakat Sunda dihadirkan melalui kemunculan tokoh petani (budaya ladang dan sawah), ustad dan dukun, berdagang bahkan memuja setan.

\section{Sistem Religi}

Komik yang menjadi objek penelitian, bentuk ceritanya adalah the slice of life story (cerita yang mengungkapkan potongan cerita sebuah kehidupan). Cerita dalam komik ini merupakan fiksi, kejadiannya menggambarkan budaya okultisme di Sunda dengan dikenalnya istilah 4 macam praktek pemujaan pada setan atau jin. Melalui latar waktu malam Jumat Kliwon menjadi gambaran lain kepercayaan orang Sunda, pada hari yang dianggap keramat tersebut sebagian masyarakat menganggap sebagai hari dimana saatnya makhluk-makhluk ghaib berkeliaran. Masih menjadi perdebatan pengaruh dari agama Hindu, Kejawen atau Islam. Namun Islam dalam komik ini menjadi sistem religi yang dominan di masyarakat Sunda.

Kuncen atau dukun dalam komik ini merupakan orang yang menjadi perantara antara dunia nyata dan dunia ghaib. Mengenakan iket sebagai bentuk ungkapan memiliki kelebihan dalam urusan ghaib. Dalam Suciati [11] Iket dipandang dan dianggap menjadi atribut sosial. Bentuknya yang bermacam-macam diciptakan sebagai simbol yang berkaitan dengan keagamaan, upacara adat, dan status 
sosial tokoh-tokoh masyarakat yang dianggap mempunyai peranan dalam suatu kelembagaan.

Gambaran kosmologi orang Sunda yang memandang hidup sebagai kesatuan total antara dunia atas, dunia tengah, dan dunia bawah [12], hadir dengan munculnya dukun atau kuncen, yakni kepercayaan adanya orang-orang yang menjadi juru kunci antara dunia tersebut diatas, sebagai medium atau perantara yang mewakili. Kuncen dalam komik ini berperan untuk menghubungkan manusia dan alam ghaib.

Selain unsur di atas dalam ceritanya komik ini dilengkapi pula dengan humor atau banyolan Sunda, berupa pengucapan istilah yang salah, pelafalan huruf yang salah, humor tingkah laku dan lain-lain seperti yang digambarkan pada Gambar 20.

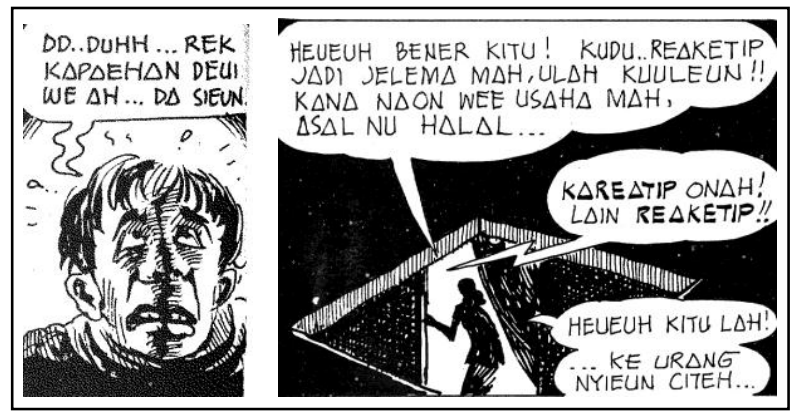

Gambar 20 Humor tokoh-tokoh dalam komik, tingkah laku dan dialog. [5]

\section{$5 \quad$ Kesimpulan}

Pada penelitian ini diperoleh kesimpulan sebagai berikut:

Terdapat ciri visual dan karakter komik Opat Madhab Setan yang hadir dalam gaya gambar. Komik Sunda ini memiliki gaya gambar semi realis dengan format warna hitam putih, cenderung gelap, tidak detail menangkap objek. Hal ini mengesankan komik dibuat dengan terburu-buru dan hasil pekerjaan yang tidak rapi. Tulisan pada komik dibuat manual dengan menggunakan huruf besar (kapital) supaya bisa dibaca dengan jelas, rapih dan lurus, sebagai bentuk kebersahajaan dan kesedehanaan komikus. Komik ini memiliki 2 panel yang sederhana yang ukurannya tidak konsisten, tidak rapih serta didominasi oleh peralihan adegan yang menunjukkan cara seorang Sunda dalam bertutur sehingga cerita cukup mudah dipahami oleh pembaca. Gabungan panel yang didominasi oleh gabungan interdependen yang menunjukkan kekayaan istilah dalam bahasa Sunda, sehingga kata tidak dapat diwakilkan oleh kata atau gambar saja, begitu pula sebaliknya. 
Ciri lainnya adalah komik ini lebih banyak menangkap objek atau pelaku secara gestural, menunjukkan cara bertutur dalam visual seorang komikus Sunda. Efek suara muncul menggunakan istilah onomatopea berasal dari bahasa Sunda, secara visual digambarkan sangat sederhana.

Terdapat representasi budaya Sunda dalam komik Opat Madhab Setan. Hadir melalui kemunculan visual yang menunjukkan unsur kebudayaan di masyarakat Sunda, unsur tersebut berupa bahasa. Bahasa yang digunakan adalah bahasa Sunda loma/lancaran sebagai bentuk egaliterisme masyarakat Sunda. Pengaruh bahasa Arab hadir pada nama beberapa tokohnya. Muncul dalam unsur instrinsik komik berupa karakterisasi (nama tokoh) dan penokohannya. Unsur bahasa lainnya dapat dilihat melalui istilah gestur dan postur.

Unsur budaya lain yang hadir dalam komik ini adalah gambaran organisasi sosial dalam sebuah masyarakat Sunda. Bentuk lainnya berupa digambarkannya arketip kepemimpinan di Sunda, bagaimana seseorang yang lebih dalam pengetahuan agama dianggap sebagai pemimpin. Melalui unsur ini dapat dilihat hadirnya strata sosial dalam masyarakat Sunda yang didasarkan kepemilikan pengetahuan dan pengalaman bukan hanya status ekonomi saja.

Sistem peralatan hidup dan teknologi menjadi unsur budaya lain yang hadir dalam komik ini, muncul melalui latar tempat, properti dan atributnya. Kampung Nanjung merupakan gambaran perkampungan Sunda. Untuk peralatan hidup digambarkan pakaian, beberapa atribut, berupa alat benda pakai, yang dikenakan oleh tokoh-tokohnya sesuai dengan karakterisasinya. Atribut lainnya hadir dalam alat bantu atau peralatan yang digunakan dalam pekerjaan sehari-hari, banyak terbuat dari material yang berasal dari alam, menunjukkan Orang Sunda menghargai alam dan memiliki pandangan bahwa alam sangat penting dalam kehidupan mereka.

Sistem mata pencaharian masyarakat Sunda dihadirkan melalui kemunculan tokoh petani yang keberadaannya tidak terlalu signifikan dan cerita ini. Namun memberikan gambaran masyarakat Sunda dengan budaya ladang atau sawahnya. Dalam budaya ini sebagian besar masyarakatnya bermata pencaharian sebagai petani. Mata pencaharian lainnya adalah ustad, profesi yang melengkapi sebuah masyarakat di Sunda. Kehadirannya selalu ada pada sebuah masyarakat yang didominasi oleh penduduk beragama Islam. Perdukunan, juga menjadi gambaran mata pencaharian bagi masyarakat Sunda yang saat ini masih dapat dijumpai di komunitas masyarakat di kampungkampung di daerah Jawa Barat.

Unsur budaya berupa sistem religi hadir melalui penokohan dan stereotype serta dialog diantara tokoh-tokohnya. Digambarkan Islam menjadi sistem religi yang 
dominan dipeluk oleh masyarakat Sunda, dan mempengaruhi kehidupan sosial masyarakatnya. Walaupun begitu gambaran lain berupa kosmologi orang Sunda dihadirkan di komik ini, diwarnai dengan adanya kepercayaan akan keramatnya hari-hari tertentu.

Orang Sunda direpresentasikan dalam komik ini melalui percakapan balon kata yang memiliki karakter senang bercakap-cakap, dan dalam kemunculan tokohnya dihadirkan tokoh yang memiliki karakter lucu, borangan (penakut) dan konyol, sebagai bentuk humor (banyolan) orang Sunda.

Kemunculan komik Sunda Opat Madhab Setan dipengaruhi oleh ketentuan dan kebijakan redaksi Mangle, salah satunya adalah ilustrasi yang melengkapi naskah kiranya mampu memberikan gambaran "Nineung ka Sunda" (kerinduan pada Sunda), Nineung ka Sunda dinterpretasi dan didefinisikan oleh komikus menurut pemahaman dan pengalaman komikus. Unsur budaya Sunda hadir melalui gambar dan tulisan saling melengkapi, bersinergis muncul dan menciptakan sebuah kekhasan dan menjadi karakter serta ciri visual sebuah komik Opat Madhab Setan.

Menjadi saran untuk penelitian berikutnya untuk mengkaji unsur lain seperti cerita, alur, gaya gambar atau unsur ekstrinsik berupa pandangan hidup komikus dan pengaruhnya pada karya yang dibuat dengan bermacam metode. Selain itu dokumentasi komik Sunda yang sangat terbatas mengakibatkan masih jarangnya penelitian yang berhubungan dengan sejarah komik Sunda.

\section{Referensi}

[1] Danesi, M. 2010. Pesan, Tanda, dan Makna: Buku Teks Dasar mengenai Semiotika, Yogyakarta: Jalasutra.

[2] Altheide, D.L. 1987. Ethnographic Content Analysis Human Sciences Press Qualitative Sociology, Arizona State University Spring 65, 10(1).

[3] Ida, R. 2001. Analisis Isi Kualitatif: Ragam Penelitian Isi Media Kuantitatif \& Kualitatif, Jakarta: Raja Grafindo Persada.

[4] Eriyanto. 2011. Analisis Isi: Pengantar Metodologi untuk Penelitian Ilmu Komunikasi dan Ilmu-Ilmu Sosial Lainnya, Jakarta: Kencana Prenada.

[5] Karung, B.R. 1988. Opat Madhab Setan, Manglé, Edisi 1136-1177, 3 Maret-22 Desember 2008, Bandung: PT. Mangle Panglipur.

[6] Ayatrohaedi. 2002. Citra Perempuan dalam Sastra Sunda, Bandung: Pikiran Rakyat.

[7] Hasbullah, M. 2000. Menjawab Misteri Langkanya Candi di Tatar Sunda, http://wacananusantara.org/content/view/category/99/id/5 (25 Februari 2012). 
[8] McCloud, S. 2001. Understanding Comics, Jakarta: Kepustakaan Populer Gramedia.

[9] Rosidi, A. 2006. Kajian tentang Falsafah Sunda (Pelatihan Kepemimpinan Putra Sunda Gema Jabar, 21 Agustus 2006), http://ajip-rosidi.com/ makalah/kajian-tentang-falsafah-sunda/ (12 Oktober 2009).

[10] Sumintardja, D. 1978. Kompendium Sejarah Arsitektur, Bandung: Yayasan Lembaga Penyelidikan Masalah Bangunan.

[11] Suciati. 2008. Karakteristik Iket Sunda di Bandung dan Sumedang Periode Tahun 1968-2006, ITB Journal of Visual Art and Design, 2(3), pp. 237-260.

[12] Sumardjo, J. 2003. Simbol-simbol Artefak Budaya Sunda Tafsir-tafsir Pantun Sunda, Bandung: Kelir. 